\title{
Potret Pendidikan di Masa Pandemi: Efektivitas Penggunaan Aplikasi Zoom sebagai Media Belajar Daring di Masa Pandem
}

\author{
Dinda Riza Syahnaz ${ }^{1}$, Rizqia Fitri Siregar². Nurainun Siregar ${ }^{3}$. \\ Tadris Bahasa Inggris, Fakultas Ilmu Tarbiyah dan Keguruan \\ Universitas Islam Negeri Sumatera Utara \\ * Corresponding Author. E-mail: dindarizasahnaz@gmail.com, rizqiafitrisrg@gmail.com, \\ Nurainunsiregartbi1@gmail.com
}

Receive: $18 / 08 / 2021$

Accepted: 23/09/2021

Published: 01/10/2021

\begin{abstract}
Abstrak
Pada masa pandemi Covid-19, pemerintah mewajibkan pembelajaran dilakukan secara online atau dalam jaringan. Aplikasi yang paling sering dalam pembelajaran dalam jaringan adalah aplikasi zoom. Penelitian ini dilakukan untuk mengetahui seberapa efektifnya penggunaan aplikasi zoom bagi mahasiswa Tadris Bahasa Inggris-1 semester VI, Universitas Islam Negeri Sumatera Utara Medan. Penelitian ini bersifat kualitatif dan menggunakan metode grounded theory. Teknik pengumpulan data dilakukan dengan kuesioner melalui Google Form kepada sepuluh mahasiswa Tadris Bahasa Inggris-1 semester VI, Universitas Islam Negeri Sumatera Utara Medan. Hasil penelitian ini, menunjukkan bahwa penggunaan aplikasi zoom efektif bagi para mahasiswa Tadris Bahasa Inggris-1 semester VI, Universitas Islam Negeri Sumatera Utara Medan. Dengan alasan banyak memberi kemudahan dan dilengkapi berbagai fitur pendukung pembelajaran dalam jaringan.
\end{abstract}

Kata Kunci: dalam jaringan, efektif, aplikasi zoom

\begin{abstract}
During the Covid-19 pandemic, the government required learning to be done online or online. The most frequent application in online learning is the zoom application. This research was conducted to find out how effective the use of the zoom application for students of Tadris English-1 semester VI, State Islamic University of North Sumatra, Medan. This research is qualitative and uses grounded theory method. The data collection technique was carried out using a questionnaire via Google Form to ten students of English Language Tadris1 semester VI, State Islamic University of North Sumatra, Medan. The results of this study indicate that the use of the zoom application is effective for students of Tadris English-1 semester VI, State Islamic University of North Sumatra, Medan. With many reasons to provide convenience and equipped with various features to support learning in the network.
\end{abstract}

Keywords: online, effectiveness, zoom aplication

\section{Pendahuluan}

Corona Virus Disease atau Covid-19 menjadi suatu kasus di tahun 2019 yang mengakibatkan semua orang harus jaga jarak dan menjauhi kerumunan sosial. Hal ini memberi dampak pada ekonomi, sosial dan pendidikan. Pemerintah mengambil kebijakan dengan menerapkan Social Distancing untuk meminimalisir penularan Covid 19. Social distancing merupakan suatu tindakan dimana setiap orang diharuskan untuk menjaga jarak, menjaga kebersihan serta menggunakan masker guna memutus rantai penyebaran wabah virus korona.

Adanya surat edaran Kemendikbud No.2 tahun 2020 dan No.3 tahun 2020 tentang pencegahan dan penanganan Covid-19 mewajibkan lembaga pendidikan untuk 
memberlakukan pembelajaran dalam jaringan atau secara online. Oleh karena itu, guru atau dosen mulai memikirkan aplikasi apa yang baik untuk dijadikan sebagai media pembelajaran dalam jaringan. Ada banyak aplikasi yang bisa dijadikan sebagai media pembelajaran dalam jaringan, seperti Google Meet, e-Mail, Whatsapp Group, Google Classrom Room, Facebook, Zoom Meeting, E-Learning dan banyak lagi.

Zoom adalah salah satu media pembelajaran dalam jaringan yang menggunakan fasilitas interaksi tatap muka antara pendidik dengan peserta didik secara virtual melalui konferensi video dengan laptop atau smartphone. Selain itu, aplikasi zoom memiliki fitur pendukung kegiatan proses pembelajaran seperti fitur share screen yang berfungsi untuk menampilkan materi pembelajaran.

Beberapa hal yang menjadi kekurangan dan kelebihan bagi penggunaan aplikasi zoom yang dapat mempengaruhi kegiatan proses belajar mengajar. Oleh karena itu, tujuan dari penelitian ini adalah untuk mengetahui seberapa efektif penggunaan aplikasi zoom sebagai media pembelajaran dalam jaringan. Peneliti berharap penelitian ini dapat menjadi inspirasi bagi para pendidik dalam penggunaan media belajar dalam jaringan

\section{Metode}

Penelitian ini bersifat kuallitatif. Metode penelitian yang digunakan adalah metode penelitian kepustakaan, yang mengumpulkan informasi dari perpustakaan yang berupa jurnal, buku dan dokumen-dokumen lainnya. Selain menggunakan metode penelitian kepustakaan, peneliti juga mengumpulkan data menggunakan menggunakan metode grounded theory dengan teknik wawancara atau pengisian kuesioner melalui Google Form yang ditujukan untuk diisi oleh peserta didik, khususnya bagi mahasiswa. Populasi adalah keseluruhan subjek penelitian, sedangkan sampel adalah sebagian dari populasiyang diteliti. Dalam penelitian ini populasi penelitian adalah mahasiswa Tadris Bahasa Inggris-1 semester VI, Universitas Islam Negeri Sumatera Utara Medan. Sedangkan sampel yang diambil sebanyak sepuluh orang mahasiswa dari kelas tersebut.

\section{Hasil dan Pembahasan}

Sejak pembelajaran dalam jaringan dimulai, kelas Tadris Bahasa Inggris-1 semester VI, Universitas Islam Negeri Sumatera Utara Medan.sering menggunakan aplikasi zoom sebagai media pembelajaran dalam jaringan. Beberapa dosen tertarik untuk menggunakan aplikasi zoom sebagai media pembelajaran dalam jaringan. Fitur utama pada aplikasi ini adalah kamera dan suara yang menjadikan tampilan pembelajaran dalam jaringan seperti keadaan nyata di luar jaringan. Ada dosen yang mewajibkan aktif kamera ada yang tidak. Ketika mahasiswa ada yang sakit, mahasiswa tersebut dapat mematikan kameranya, hal ini sangat menguntungkan dalam keadaan sakit. Karena tetap bisa belajar seperti biasa walaupun dalam keadaan sakit. Hal menguntungkan lainnya adalah ketika Host merekam pembelajaran. Maka, setiap ada hal yang terlupa atau ada yang tidak masuk dapat melihat proses pembelajaran dengan melihat video rekaman yang ada. Fitur pendukung yang disediakan berupa share screen yang dapat ditampilkan sebagai bentuk penjelasan dari dosen. Selain itu ada fitur emoji dan raise hand yang berguna sebagai pemberi tanda mahasiswa ingin bertanya. Selain menggunakan laptop, pengguna aplikasi zoom ini juga dapat menggunakan smartphone.

Saya menggunakan kuesioner untuk mendapatkan data-data dari sampel yang dituju. Beberapa data yang dimaksud sebagai berikut:

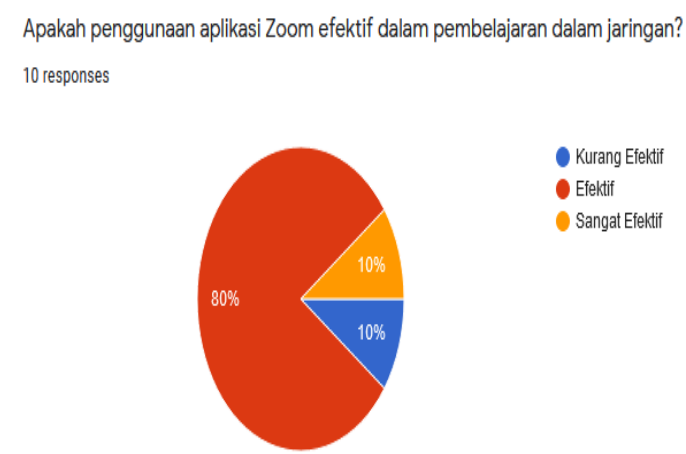

Diagram tingkatan efektivitas aplikasi zoom

Dilihat dari diagram lingkaran tersebut bahwa $80 \%$ aplikasi zoom efektif digunakan sebagai media pembelajaran 
dalam jaringan. Terlihat bahwa dari sepuluh mahasiswa yang menjadi sampel, delapan mahasiswa menjawab efektif. Satu siswa dari sepuluh mahasiswa menjawab kurang efektif dan satu mahasiswa lainnya menjawab sangat efektif. Dari diagram ini dapat disimpulkan bahwa aplikasi zoom merupakan media yang efektif dalam pembelajaran dalam jaringan. Beberapa hal yang menjadi alasan beberapa mahasiswa adalah sebagai berikut.

\begin{tabular}{|c|c|c|c|c|}
\hline No & Nama & $\begin{array}{c}\text { Keuntungan dalam } \\
\text { penggunaan } \\
\text { aplikasi zoom }\end{array}$ & $\begin{array}{l}\text { Kendala dalam } \\
\text { penggunaan } \\
\text { aplikasi zoom } \\
\end{array}$ & $\begin{array}{c}\text { Kepahaman dalam } \\
\text { penggunaan aplikasi } \\
\text { zoom }\end{array}$ \\
\hline 1 & Partisipan a & $\begin{array}{l}\text { Ketika presentasi } \\
\text { kita dapat } \\
\text { mendengarkan } \\
\text { materi ketimbang } \\
\text { materi dalam } \\
\text { bentuk voice note }\end{array}$ & Di signal & $\begin{array}{l}\text { Paham, karena lebih } \\
\text { mudah } \\
\text { mendengarkan } \\
\text { penjelasan dosen via } \\
\text { zoom }\end{array}$ \\
\hline 2 & Partisipan b & $\begin{array}{l}\text { Merasa seperti } \\
\text { belajar offline, } \\
\text { dapat melihat } \\
\text { dosen yang } \\
\text { menjelaskan dan } \\
\text { melihat teman- } \\
\text { teman }\end{array}$ & $\begin{array}{l}\text { Kendala sinyal, } \\
\text { ketika sinyal } \\
\text { rendah maka zoom } \\
\text { akan macet-macet } \\
\text { atau terkadang } \\
\text { nge-freeze dan } \\
\text { zoom sangat } \\
\text { banyak memakai } \\
\text { kuota internet }\end{array}$ & $\begin{array}{l}\text { Paham, karena } \\
\text { penjelasannya lebih } \\
\text { jelas dan kita dapat } \\
\text { melihat orang yang } \\
\text { menjelaskan }\end{array}$ \\
\hline 3 & Partisipan c & $\begin{array}{l}\text { Keuntungan kita } \\
\text { jadi nampak visual } \\
\text { dosennya }\end{array}$ & $\begin{array}{l}\text { Jaringan yang } \\
\text { kadang lelet dan } \\
\text { sering buat keluar } \\
\text { sendiri dan ketika } \\
\text { masuk nggak di } \\
\text { admit dosennya }\end{array}$ & $\begin{array}{l}\text { Rada paham karena } \\
\text { disitu wajah kita } \\
\text { terlihat semua dan } \\
\text { tidak beda jauh } \\
\text { sama offline }\end{array}$ \\
\hline 4 & Partisipan d & $\begin{array}{l}\text { Aplikasi zoom lebih } \\
\text { lengkap fasilitasnya } \\
\text { dibandingkan } \\
\text { aplikasi conference } \\
\text { yang lain, dimana } \\
\text { aplikasi zoom ini } \\
\text { memberikan } \\
\text { pelayanan suara } \\
\text { yang jernih, berbagi } \\
\text { layar, dan fitur } \\
\text { menarik lainnya } \\
\end{array}$ & $\begin{array}{l}\text { Kadang-kadang } \\
\text { zoom saya } \\
\text { terkendala hanya } \\
\text { karena jaringan } \\
\text { saja }\end{array}$ & $\begin{array}{l}\text { Paham, karena saya } \\
\text { sudah terbiasa } \\
\text { menggunakannya }\end{array}$ \\
\hline 5 & Partisipan e & $\begin{array}{l}\text { Dengan adanya } \\
\text { aplikasi zoom, } \\
\text { mempermudah } \\
\text { pembelajaran } \\
\text { dimasa pandemi } \\
\text { saat ini }\end{array}$ & $\begin{array}{l}\text { Masalah jaringan } \\
\text { yang tidak } \\
\text { mendukung }\end{array}$ & Paham \\
\hline 6 & Partisipan $\mathrm{f}$ & $\begin{array}{l}\text { Pembelajaran } \\
\text { daring nya efektif } \\
\text { karena bisa } \\
\text { bertatap wajah } \\
\text { walau dari aplikasi } \\
\text { dan bisa share } \\
\text { screen }\end{array}$ & $\begin{array}{l}\text { Aplikasi tersebut } \\
\text { harus benar-benar } \\
\text { menggunakan } \\
\text { signal yang bagus } \\
\text { dan tidak semua } \\
\text { pelajar bisa } \\
\text { memastikan signal }\end{array}$ & $\begin{array}{l}\text { Kalo saya sendiri } \\
\text { InsyaAllah paham, } \\
\text { masalah paham atau } \\
\text { tidaknya itu } \\
\text { tergantung } \\
\text { pelajarnya dalam } \\
\text { pembelajaraan }\end{array}$ \\
\hline
\end{tabular}


Jurnal Edumaspul, 5 (2), Year 2021- 623

(Dinda Riza Syahnaz, Rizqia Fitri Siregar. Nurainun Siregar)

\begin{tabular}{|c|l|l|l|l|}
\hline 7 & Partisipan g & $\begin{array}{l}\text { Kita bisa belajar } \\
\text { gratis dari aplikasi } \\
\text { ini }\end{array}$ & $\begin{array}{l}\text { di lokasinya bagus } \\
\text { tiap pembelajaran } \\
\text { kongan, terkadang } \\
\text { keseorang tidak } \\
\text { stabil }\end{array}$ & $\begin{array}{l}\text { mengunakan zoom } \\
\text { tersebut }\end{array}$ \\
\hline 8 & Partisipan $\mathrm{h}$ & $\begin{array}{l}\text { Lebih terasa seperti } \\
\text { berada di dalam } \\
\text { kelas. Fitur-fitur di } \\
\text { zoom juga sangat } \\
\text { berguna }\end{array}$ & $\begin{array}{l}\text { Wajib punya } \\
\text { jaringan yang baik }\end{array}$ & $\begin{array}{l}\text { Lumayan, } \\
\text { tergantung fokus } \\
\text { atau tidaknya } \\
\text { mengikuti pelajaran }\end{array}$ \\
\hline 9 & Partisipan i & $\begin{array}{l}\text { Bisa tatap muka \& } \\
\text { share screen }\end{array}$ & Kendala jaringan & Mudah dipahami \\
\hline 10 & Partisipan j & $\begin{array}{l}\text { Keuntungannya } \\
\text { lebih efektif dan } \\
\text { dapat digunakan } \\
\text { diamana pun dan } \\
\text { kapan pun }\end{array}$ & $\begin{array}{l}\text { Terkendala dari } \\
\text { signal dan kuota } \\
\text { yang cukup banyak }\end{array}$ & Lumayan paham \\
\hline
\end{tabular}

Beberapa diantara keuntungan yang diperoleh dari aplikasi zoom adalah dapat belajar virtual seperti belajar offline, bisa share screen dan dilengkapi berbagai fitur pendukung lainnya. Hal inilah yang menjadikan zoom menjadi salah satu aplikasi efektif yang dapat digunakan dalam pembelajaran dalam jaringan. Dalam video pengguna juga bisa menggunakan fitur background yang unik untuk menutupi background aslinya. Salah seorang partisipan mengatakan "Aplikasi zoom lebih lengkap fasilitasnya dibandingkan aplikasi conference yang lain, dimana aplikasi zoom ini memberikan pelayanan suara yang jernih, berbagi layar, dan fitur menarik lainnya" kualitas suara pada aplikasi zoom terdengar jernih serta dapat berbagi layar ini juga menjadi salah satu alasan menarik untuk menggunakan zoom sebagai aplikasi media pembelajaran dalam jaringan.

Dari beberapa partisipan yang menjawab kendala pada aplikasi zoom, sebagian besar mengatakan kendala pada zoom terdapat pada jaringan dan sinyal. Aplikasi zoom membutuhkan jaringan dan sinyal yang baik, sedangkan di wilayah pedesaan hal itu tidak bisa dipastikan selalu baik. Kendala lainnya adalah aplikasi zoom memakan kuota cukup banyak. Menurut saya hal ini wajar, karena kualitas yang diberikan sangatlah baik.

Dari beberapa partisipan yang menjawab pertanyaan saya mengenai kepahaman mereka terhadap pembelajaran menggunakan aplikasi ini, sebagian besar menjawab paham. Semua itu kembali kepada pengguna masing-masing, jikalau fokus dan konsentrasi semua yang dijelaskan akan lebih mudah dipahami. Alasan terbesar menjawab paham adalah karena mereka merasa seperti belajar offline yang mana dapat bertatap wajah langsung secara virtual dalam jaringan.

Dari beberapa aplikasi sebagai media pembelajaran dalam jaringan, apakah aplikasi Zoom menjadi salah satu media pembelajaran favorit Anda? 10 responses

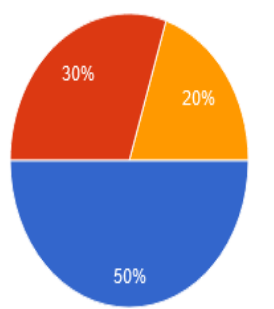

- Ya

Biasa Saja - Tidak Benar Sekali

Diagram pernyataan seberapa favorit aplikasi zoom

Pertanyaan terakhir saya terhadap partisipan adalah apakah mereka menjadikan zoom sebagai aplikasi terbaik dalam pembelajaran dalam jaringan, sebagian besar partisipan menjawab "Ya". Sebesar 50\% atau sebanyak lima mahasiswa dari sepuluh mahasiswa menjawab ya, aplikasi zoom merupakan salah satu aplikasi favorit dalam pembelajaran dalam jaringan. Setiap mahasiswa memiliki persepsi masing-masing, tiga mahasiswa menjawab bahwa aplikasi zoom menjadi aplikasi yang biasa saja dalam pembelajaran dalam jaringan, dan dua 
Jurnal Edumaspul, 5 (2), Year 2021- 624

(Dinda Riza Syahnaz, Rizqia Fitri Siregar. Nurainun Siregar)

mahasiswa menjawab bahwa aplikasi zoom bukanlah aplikasi favorit mereka dalam pembelajaran dalam jaringan. Dapat disimpulkan bahwa aplikasi zoom banyak memberi kemudahan dan dukungan dalam pembelajaran dalam jaringan, hal inilah yang menjadikan zoom menjadi salah satu aplikasi favorit sebagai media dalam pembelajaran dalam jaringan.

\section{Simpulan}

Dalam masa pandemi Covid-19 pemerintah mewajibkan proses pendidikan berjalan secara online atau dalam jaringan. Hal ini bertujuan untuk memutus rantai penyebaran wabah virus korona. Social Distancing tidak melunturkan semangat jiwa pendidik serta peserta didik dalam belajar, oleh karena itu pendidik mencari cara efektif dalam proses pembelajaran. Dari beberapa aplikasi media pendukung dalam pembelajaran dalam jaringan, aplikasi zoom adalah salah satunya.

Zoom adalah aplikasi yang menggunakan video conference. Aplikasi zoom ini tidak hanya dipergunakan dalam sistem pendidikan, namun juga digunakan dalam pekerjaan. Aplikasi zoom memudahkan setiap orang dalam melakukan komunikasi virtual dengan orang banyak. Aplikasi zoom memiliki banyak fitur yang dapat memudahkan penggunanya. Hal inilah yang menjadi aplikasi zoom menjadi salah satu aplikasi yang diminati oleh pendidik dan peserta didik sebegai media pembelajaran dalam jaringan.

Aplikasi zoom menjadi salah satu aplikasi efektif dan favorit bagi mahasiswa Tadris Bahasa Inggris-1 semester VI, Universitas Islam Negeri Sumatera Utara Medan. Kendalanya hanya di jaringan dan memakan kuota yang cukup banyak. Namun hal itu adalah hal yang wajar menurut peneliti, karena kualitas aplikasi zoom sendiri sangatlah baik dan dilengkapi dengan berbagai fasilitas atau fitur pendukung dalam proses pembelajaran dalam jaringan.

Sebagian besar partisipan juga paham belajar dengan aplikasi zoom ini. Tetapi itu semua kembali pada diri masing-masing. Selama fokus, konsentrasi dan sungguh-sungguh, pasti ada jalan kemudahan dalam memahami segala pelajaran yang ada.

\section{Daftar Pustaka}

[1] Abidin, Rumansyah, \&Arizona, K. 2020. Pembelajaran Online berbasis Proyek Salah Satu Solusi Kegiatan Belajar Mengajar di Tengah Pandemi COVID19. Jurnal Ilmiah Profesi Pendidikan, Vol. 5 (1).

[2] Adam, Steffi dan Muhammad Taufik Syastra. 2015. Pemanfaatan Media Pembelajaran Berbasis Teknologi Informasi Bagi Siswa Kelas X Sma Ananda Batam, CBIS Journal, Vol.3 (2).

[3] Arikunto. 2002. Prosedur Penelitian Suatu Pendekatan Praktek. Jakarta: Rineka Cipta.

[4] Danin Haqien \& Aqililah Afiifadiyah Rahman. 2020. Pemanfaatan Zoom Meetinguntuk Proses Pembelajaranp pada Masa Pandemi Covid-19, Jurnal Susunan Artikel Pendidikan, Vol. 5 (1).

[5] Purwono, Joni dkk. 2014. Penggunaan Media Audio-Visual Pada Mata Pelajaran Ilmu Pengetahuan Alam Di Sekolah Menengah Pertama Negeri1 Pacitan. Jurnal Teknologi Pendidikan dan Pembelajaran Vol.2 (2).

[6] Sofyana \& Abdul. 2019. Pembelajaran Daring Kombinasi Berbasis Whatsapp Pada Kelas Karyawan Prodi Teknik Informatika Universitas PGRI Madiun, Jurnal Nasional Pendidikan Teknik Informatika. Vol.8 (1). 